\title{
Bisexuals in space and geography: more-than-queer?
}

\author{
EMIEL MALIEPAARD
}

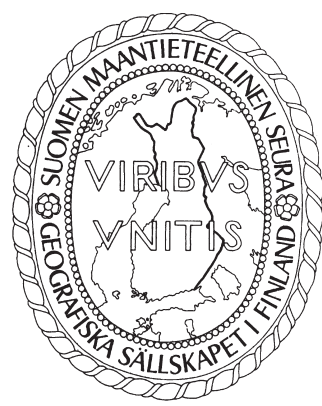

Maliepaard, Emiel (2015). Bisexuals in space and geography: more than queer? Fennia 193: 1, pp. 148-159. ISSN 1798-5617.

Geographies of sexualities mainly focusses on the lived experiences and sexual identity negotiations of gay men and lesbian women in a society based upon binary divisions of sex, gender, and sexualities. This review article wants to consider a more theoretically informed relational approach to understand the creation and sustaining of the binary system, and the everyday lived experience of bisexuals. This article will review contemporary studies on queer space and studies on the intersections of bisexual theory and queer theory. Drawing inspiration from queer theory, speech act theory, and relational geographies, I propose a focus on encounters, language, embodied practices, and embodied experiences to understand the lives of sexual minorities, and bisexuals in particular. While heteronormativity and monosexuality are important factors (or contexts) in the everyday lived experience, they are not all determining for the everyday experiences of people who desire more-than-one gender.

Keywords: bisexual spaces, more-than-representational theories, queer theory, queer space, language, practices

Emiel Maliepaard, Department of Human Geography, Institute for Management Research, Radboud University Nijmegen, Thomas van Aquinostraat 3, 6525GD Nijmegen, the Netherlands. E-mail: e.maliepaard1@gmail.com

\section{Introduction}

It has been concluded before that geographies of sexualities lack research on bisexuals, bisexual spaces, and bisexual geographies (Bell 1995; Binnie \& Valentine 1999; Hemmings 1997, 2002; McLean J 2003). Hemmings (1997), in Queers in space, observed that clear demarcated bisexual spaces do not exist, except from some conference spaces and specific bisexual support groups. These conclusions that demarcated bisexual spaces do not exist (see Hemmings 1997; McLean J 2003) can be traced down to dominant ideas on sexual spaces which are based upon a one-to-one link between the sexual coding of space(s) and the dominant sexual identity in those spaces. As concluded by Hemmings, bisexuals and bisexual identities are never dominant in spaces as bisexuals are often misread as being heterosexual or homosexual and, thus, invisible (Hemmings 1997; see also McLean J 2003; McLean K 2007, 2008). She concludes that bisexuals occupy space within existing gay (and lesbian) and straight spaces; a conclusion which holds true in her theorising of sexual space as depending on a one-to-one link with the dominant sexual identity.

Similar to Bell's (1995) activist approach in challenging the placelessness of geographies of bisexualities (also Binnie \& Valentine 1999), this paper is an attempt to critically revise conceptualisations of sexual space, and bisexual space in particular. This review article approaches bisexual spaces and bisexual geographies from a more theoretical point of view by reviewing the intersections of queer theory, queer space, bisexuality theory/theorising, and more-than-representational geographies. As such, this article wants to contribute to Hemmings (1997) call for more coherent theorising of bisexual spaces. Pioneering work by Clare Hemmings (2002), her book Bisexual spaces, is understood as an excellent starting point for this paper as it successfully opens up questions on sexual spaces, bisexual spaces, and bisexuality.

Albeit my interest is mainly in the geographies of sexualities, which I read as the overarching field of queer geographies and lesbian and gay geogra- 
phies (but see Browne 2006 for a different reading), I will elaborate on intersections with queer theory and queer space and discuss the usefulness of conceptualising bisexual spaces. In this paper I aim to bring forward a more theoretical relational approach to (bi)sexual space which challenges queer space and queer theory as I favour an approach which extends norms, values, and orthodoxies, instead of (only) transgressing heterosexual norms, values, and orthodoxies of contemporary society. The paper will firstly review queer space and the intersections of queer theory and bisexuality theory, before taking a more-than-representational approach to space and the everyday embodied experiences of sexual subjects.

\section{Space (still) matters: queer space as well?}

South African sociologist Smuts (2011) concluded in her research into coming out stories of lesbians in Johannesburg: "[a]nother theme that was prominent in the participants' narratives was the importance of social space. The findings indicate that respondents' sexual identities were linked and influenced by the social spaces in which they found themselves. Some stressed that certain spaces would determine which of their identities would emerge at particular points in time, and whether they would hide their sexual identities" (2011: 32-33; emphasis added). This conclusion regarding the intertwinedness of space and identity/identities resembles both geographical inquiries into the everyday lives of sexual minorities (e.g. Bell et al. 1994; Johnston \& Valentine 1995; Myslik 1996; Valentine 1996; Kirby \& Hay 1999; Kitchin \& Lysaght 2003; Browne 2007) and geographical inquiries into affective atmospheres (e.g. Anderson 2009; Bissell 2010; Duff 2010). Space, or the sexual coding of space, impacts the sexual identity negotiations of sexual subjects as well as sexual identity negotiations influence the sexual coding of space. As such, they mutually enforce and/or challenge each other. But what about queer space?

Gay and lesbian geographies (e.g. Adler \& Brenner 1992; Forest 1995; Rothenberg 1995; Myslik 1996; Sibalis 2004; Knopp 2007; see also Brown 2014) have been enriched by a queer geographical approach since the early nineties (e.g. Bell et al. 1994; Binnie 1997, 2007; Brown 2000; Brown et al 2007; Knopp 2007). This queer geographical approach can be understood as a set of geographical adaptions of queer theoretical work. Michael Brown's (2000) Closet Space provides the closest reading of the linguistic origins of queer theory, especially the speech-act theory which partly underlies Butler's (1990, 1993) foundational work on gender and sexuality. Drawing on Austin (1975: quoted in Brown 2000), Brown (2000: 29) elaborates on the point that "sometimes the spoken or written word doesn't simply exist, but often performs some sort of task by virtue of its presence, audibly or textually". Interesting is the elaboration on etiolatic speech acts; speech acts that neither fail nor succeed but "where meaning is produced in a context where language is being used in a very self-conscious way" (Brown 2000: 29-30). The linguistic origins of queer theory are interesting as recent research suggests that language has a certain temporality and spatiality (Blommaert et al. 2005). This can be linked with the queer theoretical emphasis on the performativity of certain heterosexual norms and orthodoxies (e.g. Butler 1993), a concept which emphasises the constant repetition of certain acts, habits, and practices in order to naturalise certain norms and values as essential and part of human nature. As such, people will experience these heterosexual norms and values as natural and as a fact of life.

Although queer theory lacks notions of context, space, and place (Brown 2000), (critical) geographers have tried to introduce queer theory in geographies of sexualities, and introduce notions of space and place in queer theory in order to carve out heteronormative and queer spaces. Space is, also within queer geographies, often seen as naturally heterosexual (e.g. Bell et al. 1994; Brown 2000; Visser 2008, 2013) and this space needs to be queered by sexual minorities (e.g. Oswin 2008 for a critique; Visser 2008). Such queered spaces - or queer spaces - are dissident, loose, or transgressive spaces which provide non-heterosexuals with the opportunity to express their sexual identities as gay, lesbian, bisexual, pansexual, queer etcetera. As the Myslik (1996) study shows, gay men found the freedom and safety to be gay and to perform their gay identity and lifestyle in these spaces. Brown (2000) reiterates an encounter - "a little slice of urban life" (2000: 27) - in Capitol Hill, Seattle when a camp gay man entered a bus and a heterosexual (opposite-sex) couple seemed to challenge the behaviour of the camp gay man. This urged the gay man to loudly state: "well if you don't like it, girlfriend, what the hell you doin' up 
on Capitol Hill in the first place!" (2000: 27; emphasis in the original). While I was, of course, not part of these encounters, the statement of the camp guy can be read as a "queer act" to resist heterosexuality and heteronormativity, and to claim queer space: Capitol Hill is queer. Academically, as well as societally, we seem to identify spaces in binary and exclusive language: heterosexual versus gay/lesbian/queer space.

Important, reflexive, work on queer space has been done by Oswin (2008) who observed that queer space is often seen, by critical geographers, as a "space of resistance" or a space which is inhabited by gay men, lesbian women, and/or queers. She continues by saying, "in the work of Bell, Binnie, Valentine, and others queer space is thus established as a concrete space that is carved out by sexual dissidents (read: gays and lesbians)" (Oswin 2008: 90; also Browne \& Bakshi 2011). As such we can wonder to which extent queer geography succeeded in rendering space fluid, still one of the hallmarks of queer geographies (see Browne 2006). In this work, queer spaces are not only seen as spaces of resistance, but also as spaces which are relatively free from the influences of heteronormativity and free of heterosexual people. Wayne Myslik (1996: 156) observed that according to "gay men who are at risk of prejudice, discrimination and physical and verbal violence throughout their daily lives (...) queer spaces are generally perceived as safe havens from this discrimination and violence". Myslik (1996: 168) concludes with the observation that "queer spaces create the strong sense of empowerment that allows men to look past the dangers of being gay in the city and to feel safe and at home". Such a conclusion resembles work on gay and lesbian spaces in which these spaces are often seen as liberal spaces.

Discussing the need for safe spaces for bisexuals, Jo Eadie (1993) argues that such spaces are needed for a number of reasons. In the first place, Eadie argues that bisexuals need a space free from oppressive regimes and social groups. We can understand this as free from gay, lesbian, and straight communities and orthodoxies. This point indeed resembles much work on queer space and gay and lesbian geographies that tried to carve out safe havens for gay men and to a lesser extent lesbian women. A second reason is the need for bisexuals to share similar experiences and set agendas for bisexual activists; a very political reading of bisexual spaces which emphasises the importance of bisexual space to unite bisexuals, empower bisex- uals, and pave the path for bisexual activists/activism. Thirdly, and finally, Eadie describes bisexual safe spaces as places free of fears and anxiety caused by members of oppressive groups. This third reason resembles, again, work on gay and lesbian spaces as liberal spaces and spaces of resistance. In short, we can understand that this call for bisexual safe spaces is relatively utopian and based upon similar assumptions as, for instance, the gay men in the Myslik study. Although I understand the political reasons behind the call for bisexual safe spaces, I doubt that such idealistic and utopian spaces would exist beyond the clear demarcated bisexual spaces as identified in early work by Hemmings (1997).

Regarding nightlife spaces for sexual minorities youth, both Valentine and Skelton (2003) as well as Holt and Griffin (2003) refer to gay and lesbian nightlife as nightlife in which sexual minority youth can live (and explore) their sexual identity, free from everyday sexual identity negotiations and constraints in heterosexual life. It is interesting that both studies acknowledge that gay and lesbian nightlife also should be understood as loose and risky spaces where social pressure renders gay and lesbian youth uncertain. The paradoxal nature of the gay and lesbian scene, already, provides a critique towards the conceptualisations of queer space as demarcated "space of resistance" against heterosexism and heteronormativity which organises contemporary society and everyday public and private space (see also Johnston \& Valentine 1995; Duncan 1996).

Oswin (2008), discussing the Nash and Bain (2007) article on Toronto queer spaces, points out that multiple processes of exclusion are in play in everyday spaces. Power is everywhere and is negotiated in everyday encounters between people (and non-human entities). Of course, not only sexual identities are negotiated, processes of racism, ageism, sexism, class-discrimination, and genderism, amongst others, should not be forgotten. A review by Johnston and Longhurst (2008) comes to a similar conclusion and criticised Anglo-American studies into sexuality for its narrow focus on sexuality. They argue that work on sexuality in Australia, New Zealand, and the Asia-Pacific region “doesn't just pay attention to sexuality, but rather to the intersections between sexuality, postcoloniality, indigeneity, 'race', and racism" (Johnston \& Longhurst 2008: 251-252). From the United Kingdom, Gill Valentine (2007) shows how different social categories intersect in multiple stories 
in the life of a D/deaf lesbian woman and how she experienced multiple forms of exclusion in her everyday life. Also several studies on the gay scene show that sexual minority people are excluded in certain spaces (e.g. Hemmings 2002; Binnie \& Skeggs 2004; Bassi 2006; McLean K 2008; Brown 2009). Regarding gaybourhoods it has been noted that such spaces are often male dominated and predominantly 'white' (Brown 2014). AngloAmerican work on queer space, thus, could be criticised on the basis of its narrow focus on gay and lesbian identities in a heteronormative world, without taken into account other sexual identities and other kinds of exclusion which affects the life of sexual minorities too.

\section{Queer theory and bisexuality: mismatch?}

"Yet, as an effect of modernity, sexuality is far from being objective or scientific. Indeed, it is predicated on Western definitions of love, which, in its romantic and erotic expressions, is thereby considered "superior" when it is exclusive. That is, Western "love" often relies on the imposition of a binary: we think of the lover and the beloved, the pursuer and the pursued, single or married, the man and the wife and the male and the female" (Anderlini-D'Onofrio \& Alexander 2009: 198).

A special issue of the Journal of Bisexuality (see Anderlini-D'Onofrio \& Alexander 2009) is dedicated to the intersections, connections and discussions between queer theory and bisexual theory and theorising. Of course, it should be said that bisexual theory and theorising is relatively new (Angelides 2006) and often assumed to be rather weak (De Plessis 1996). The conclusions of this collection are, nevertheless, quite straightforward. It is observed that queer theory ignored, and continues to ignore, issues of bisexuality and bisexual identities (Callis 2009; Erickson-Schroth \& Mitchell 2009; Gurevich et al. 2009). The reason for this ignorance is found in the way that queer theories benefit certain sexual identities, in particular gay identities (see Yoshino 2000; Angelides 2006; Callis 2009; Erickson-Schroth \& Mitchell 2009; Gurevich et al 2009). Erickson-Schroth and Mitchell (2009) go one step further by arguing that homosexuality is prioritised and privileged to a level similar to the institutionalisation of heterosexuality or heteronormativity. Building upon The erase of bisexuality (Yoshino 2000) the authors argue that there might be a compromise between the heterosexual and homosexual/lesbian community, that both communities do not mention bisexuality in order to erase the existence of a sexual identity that falls outside the binary division of sex, gender, and sexuality. While I think that this is perhaps too radical, the concept of (compulsory) monosexuality or monosexism is very useful as it identifies a social ideology that one-to-one links sexual activities/performances with sexual identities (e.g. Ault 1996; James 1996; Hemmings 2002; Gurevich et al. 2009; Green et al 2010). Sexual performances and activities with someone from the opposite sex leads to the conclusion that someone is heterosexual, while activities with someone from the same sex lead to the conclusion that someone is gay or lesbian. Bisexuality, as sexual identity which is not limited to a person of one sex or gender, is thus made invisible and non-existing. Interestingly, James (1996) understands monosexism or compulsory monosexuality as essential part of the heterosexist or heteronormative system that polices our desires. The concept of monosexuality is a useful analytical tool and a constant reminder of the privilege of certain types of heterosexuality and homosexuality in our society.

The special issue of the Journal of Bisexuality, a couple of years later published in the book Bisexuality and queer theory (Alexander \& AnderliniD'Onofrio 2012), also discusses the added value of bisexual theory to enrich queer theory via several different perspectives. Interesting is the article by Callis (2009) who discusses the seminal work of Foucault (1978) and Butler (1990). The discussion on Butler is particularly interesting as bisexuality is often seen as a sexual identity - if already authentic - which enforces the binary system of sex, gender, and sexualities as it represents the middle ground (see Hemmings 2002; Lingel 2009). Work by Fritz Klein and Alfred Kinsey - albeit they both incorporate bisexuality - considers bisexuality as the middle ground between heterosexuality and homosexuality as such work still relies on the sex binary, gender binary, and the rigid link between gender and sexual identity. In fact, "Even the term bi-sexual denotes that the person who identifies with this term is attracted to two different things, reinforcing the gender binary, and also excluding transgender and intersex people as objects of affection" (Erickson-Schroth \& Mitchell 2009: 304). Steven Angelides (2006), building upon his book $A$ history of bisexuality (Angelides 
2001), argues that "in the history of discourses of sexuality bisexuality is both the stabilising and destabilising element in the epistemic construction of sexual identity; Its erasure in the present tense stabilises the hetero/homosexual opposition whilst simultaneously and perpetually destabilising the very terms of the opposition" (Angelides 2006: 142). Angelides (2006: 142) continues to argue that bisexuality "has been the category through and against which modern sexual identity itself has been discursively constructed".

Callis (2009: 227-228) criticises queer theory as she observes that "[Judith] Butler does not address bisexuality in her arguments about the interconnectedness of sexuality and gender, nor in her section on the performative nature of gender (...). When addressing gender performativity, she turns specifically to the process of drag. However, I believe that bisexuality, taken as an identity, serves as a way of starting gender trouble". Butler prefers to discuss homosexuality and especially lesbian identities when discussing the assumed interconnection between sexuality and gender. It seems that Butler fell in the monosexual trap when challenging heteronormativity and the constant repetition of heterosexual norms, values, and orthodoxies. Callis (2009: 228), however, discusses the potential of including bisexuality in queer theoretical discussions to deconstruct the link between gender and sexual identity by arguing that "bisexuality (...) cannot be so easily matched, because it does not allow gender to be wholly tied with sex object choice. If a person is choosing both sexes as erotic partners, her or his gender cannot be matched with sexuality". Thus, Callis approaches queer theory as being a contemporary result of constantly being embedded in heteronormative and monosexual thinking (see also Du Plessis 1996). Next, Callis (2009) argues that the bisexual's choice for both men and women challenges notions of femininity and masculinity as this option, again, is not present in our perception of femininity and masculinity. While Butler focusses on drag performances to address gender roles, focussing on bisexuals' negotiating and changing gender roles in everyday life could be fruitful to challenge the rigid distinction between man/woman, male/female, and masculinity/femininity. To summarise, bisexuality has the option to both cause "gender trouble" and question the interconnection between sexuality and gender; thus it has the potential to challenge the compulsory monosexuality and heteronormative discourse that governs contemporary sexual politics, desire, and society.

A similar conclusion can be found in EricksonSchroth and Mitchell (2009) who argue that bisexuality has not only the option to question the monosexual social ideology of sexuality but also question and destabilise the heterosexist binary system of sex, gender, and sexualities in general. As such, the authors hope that merging bisexual theory and queer theory would result in a shift from a monosexual paradigm towards a more open-ended paradigm. Not surprisingly they conclude that "by focusing on the relationship between homosexuality and heterosexuality, queer theory has stopped short of addressing the structures of power that underlie our organization of sexuality - something bisexuality speaks to on a daily basis" (Erickson-Schroth \& Mitchell 2009: 312-313). Angelides (2006), however, warns that queer theory is too busy with reinforcing the heterosexual/homosexual binary, by focussing on (homosexual and heterosexual) identities, instead of focussing on the historical and epistemological forces that constructed and still construct the binary discourse of sexualities.

Erickson-Schroth and Mitchell (2009) are not the only ones who identify an added value of bisexuality for queer theory or, broader, sexualities research. Gurevich et al. (2009) touch upon another important added value of bisexuality theory or research: knowledge production regarding sexual subjects. They argue that "in considering how sexualities are theorised, examining the bisexual frame can expand the domain of questions that address how knowledge about sexual subjects is produced, disseminated and regulated, and how sexual subject positions are taken up, deployed, or rejected" (Gurevich et al. 2009: 247). This could be read as addressing the dominant heterosexist and monosexist system, but also as a focus on the concrete impacts of this system on how sexual subjects negotiate this system. The authors take this argument further by arguing - based on sociologist and queer theorist Seidman - that the basis of queer theory is on exploring how the heterosexual/homosexual boundary as a power/knowledge regime shapes behaviour, social institutions, and the everyday social environment. This suggested focus on how life takes shape as a spatial and temporal result of the compulsory monosexual heterosexist system could be understood as a call to geographers and other social scientists to engage with the everyday - and embodied - experiences of bisexual sexual subjects. 


\section{Geographical inquiries}

Taking up the above mentioned observations by Gurevich et al. (2009) and Angelides (2006) regarding knowledge production, I am convinced that geographers can contribute to knowledge production by focussing on the everyday lives of bisexuals. Unfortunately, contemporary empirical geographical research on this topic is lacking (but see McLean J 2003) which requires us to focus upon other social sciences for empirical studies. One of the rare -but important - studies is conducted by Hemmings (2002) who explored bisexual spaces based upon her own experiences in the USA and the UK. Building upon gay and lesbian geographies, she provides the reader with a cartography of bisexuality. In essence, her argumentation that space is representation makes it difficult to identify bisexual spaces seeing the difficulties of bisexual representation in word and visuals (Bereket \& Brayton 2008; Hartman 2013). Derived from epistemological concerns, Hemmings (2002) provides a number of examples regarding bisexual spaces; the point is that these spaces are defined on their relation with gay, lesbian, and straight spaces. A quite similar study, although related to communities instead of spaces, has been conducted in the USA (Rust 2000) which, interestingly, provides mental maps of bisexuals how they relate bisexual communities with straight, lesbian, and gay communities. The point is, however, that bisexual communities are rather difficult to identify. I think that bisexual spaces, as conceptualised via relating with gay, lesbian, and straight spaces would face the same difficulty. Not surprisingly, Hemmings (2002) concludes that spatial theorising and bisexual theory do not always sit comfortable with each other. I would like to add that especially the one-to-one link between sexual space and dominant sexual identity makes it more difficult to explore bisexual spaces. The emphasis on spaces as representations adds, in my opinion, to the difficulty of identifying bisexual spaces as bisexuality is often erased or made invisible because of the dominant monosexual discourse in contemporary society.

$\mathrm{I}$, also, find geographical inspiration in morethan-representational geographies (e.g. Lorimer 2005, 2008; Laurier \& Philo 2006; Thrift 2007; Anderson \& Harrison 2010a; Laurier 2010; ) to focus on knowledge production regarding the heterosexual/homosexual binary, gender binaries, and monosexuality. Especially work by David Crouch on allotment gardening and caravanning - quite far away from the field of sex, gender, and sexualities - is inspirational and insightful for proposing an alternative approach to sexual space, sexual identity negotiations, and embodied experiences in everyday public and private space.

Crouch (2003: 1945) seeks "to bring the discussion of space closer to a practical realisation of performativity and explore the potential of the individual to reconstitute life through an articulation of spacing". The concept of 'spacing' is used "to identify subjective and practical ways in which the individual handles his or her material surroundings. Spacing is positioned in terms of action, making sense (including the refiguring of "given space"), and mechanisms of opening up possibilities" (Crouch 2003: 1945). Thus, spacing can be understood as the actions taken as response to the embodied and sensory experiences of mundane activities. People make sense of everyday encounters and events through the body (e.g. Hetherington 2003; McCormack 2003; Macpherson 2009; Middleton 2010; Nayak 2010). Crouch (2001) argues that the human body does not only make sense of space by sensory and embodied experiences, but also by doing - he defines this as feeling-by-doing (also Harrison 2000; Crouch 2001; Anderson \& Harrison 2010b). This concept shows that the embodied practice or performance itself, the doing, is the basic modus of experiencing everyday life.

In the words of Hayden Lorimer (2005: 84) when describing the focus of more-than-representational theories: "the focus falls on how life takes shape and gains expression in shared experiences, everyday routines, fleeting encounters, embodied movements, precognitive triggers, practical skills, affective intensities, enduring urges, unexceptional interactions and sensuous dispositions". While I agree with Lorimer (2005) to focus upon seemingly insignificant encounters, and the doing in these kind of encounters, I would like to add a focus on the encounters between two or more bodies in which surprise, tension, or conflict is present (see Sara Ahmed 2000). Such remarkable encounters might be less abundant, but definitely have an impact on the embodied and sensory experiences of people.

Geographies of sexualities always focused on the human body in space, however, only a limited number of studies focussed on the intersections of geographies of sexualities and more-than-representational geographies (e.g. Lim 2007; Brown 
2008). For instance, Gavin Brown's (2008: 929) inspirational analysis of cruising in public toilets in several parts of London shows the importance of the human body in the experience of the cruising practice: "the affective cruising encounters witnessed in this paper exceed the limits and expectations placed on bodies by preconceived understandings of sexuality and sexual identities". The human body, the sexualised human body, has the potential to perform many roles in everyday space and these performances are continuously negotiated in practices and encounters. As Brown shows, the body tries to make sense of the material surroundings - "ceramics of a urinal, the clothing men wear, the grass and the ivy in a cemetery, the midges on the common at dusk, amyl nitrate, or the aroma of stale sweat and urine" (Brown 2008: 929) - and open up possibilities for affective sexual cruising encounters. Although I do not want to posit that sexual space is the only space in which the practice of sex and sexualities are performed, this paper clearly shows how the cultural values and contexts influence the embodied and affective experiences of the men cruising, but not more than the material surroundings do.

Regarding identities, Crouch (2003: 1958; emphasis added) argues that: "Identities may be characterised in practice and performativity, and then negotiated in contexts. Through our bodies we expressively perform who we are. The fluidity and openness of performativity may be used to refigure identities, working alongside (other) contexts". Identities are negotiated and formed in practices and performed through the human body. Crouch explains contexts as social categories or attributes such as gender or culture/cultural values. These contexts come together in an encounter or practice, however we should be careful by prioritising certain contexts over others. Of course, we need to take into account the above described heterosexual/homosexual binary, monosexuality, as well as the sex and gender binaries in geographies of sexualities when studying the everyday life experiences and sexual identity negotiations of bisexuals, and other sexual minority groups. The point is, however, that such processes of monosexuality and binary thinking, or 'contexts', are not all determining in doing bisexuality. The focus on bisexual bodies could provide insight into the personal experiences of bisexuals and their negotiations of the different contexts. How do these contexts contribute to the affirmation, negation, or (more neutral) the negotiation of bisexuality and bisexual identi- ties? In essence, how do bisexual bodies make sense of their material and social surroundings?

Before-mentioned work on affective atmospheres (Anderson 2009; Bissell 2010; Duff 2010) discusses how identities are influenced by space. Inspired by more-than-representational geographies I posit that spaces are "temporal-spatial stabilisations of social (including linguistic) practices". Extrapolating from this working definition, sexual spaces are, thus, temporal-spatial stabilisations of social and sexual practices. Following this, I build upon Crouch (2001: 69) who argues that "through activities and dispositions, touch and movement, it is possible to express feeling, subjectivity, and unique personality that endow spaces with particular value". The body is, then, the means to express the "emotional relationship with - and in - its immediate surrounding world" (Crouch 2001: 69). Bodies are influenced by space, but also have an impact on the coding of space via activities and dispositions, touch and movement. Identifying bisexual practices and bisexual spaces, thus, is an important exercise to understand the production, reproduction, negotiations, and contestations of sexual space and bisexuality as sexual identity.

\section{A way forwards: focus on mundane spaces and practices}

As stated by Erickson-Schroth and Mitchell (2009: 312), "homosexuality, heterosexuality, and bisexuality are categories based on the sex or gender of those to whom an individual is attracted. Although this system is convenient, it is by no means selfevident". This quote inspires me in two ways. Firstly, it acknowledges that sexual identity categories - heterosexual, homosexual, and bisexual - do exist and are often convenient in everyday lives. We, society, need these categories as it provides guidelines for identification, as much as many bisexuals reject labels and embrace a society without 'boxes'. Angelides (2006: 152) argued that, "it is important to reiterate (...) that to argue that each of these terms are meaningful only in relation to the other two - that is, that each requires the other two for its self-definition - is not to argue that these terms are somehow truthful reflections of individual sexualities" (see also Oswin 2008; Gurevich et al. 2009). The second point is, of course, that the system is by no means self-evident, a conclusion 
which speaks for itself and asks for thorough investigation of the position of sexual minorities - but also of heterosexuals, their everyday life experiences, and how they deal with heteronormativity (see also Philips 2006; Hubbard 2008) and monosexuality. While the adjective "queer" is defined as an attitude to challenge existing binaries of sex, gender, sexualities, and space, and render these categories fluid (e.g. Browne 2006) - I would like to reconsider the use of queer theory and queer geography, shift away from queer space, and focus upon a more-than-representational inspired approach to understanding sex, gender, and sexualities in space. Relational theories of sexual identity, sexual identity politics, need relational theories of space to understand how sexual identity politics are played out in everyday urban and rural lives.

Nathalie Oswin (2008: 92) observes that "sexual identity politics is frequently about recognizing or accepting the 'other'. It is about extending the norm, not transgressing or challenging it". I agree with this observation and the aim to extend norms, however, to include bisexuality in sexual identity politics and sexual citizenship discussions we need to address the binary system of sexual identities (heterosexual/homosexual). Only when addressing the binary system and the monosexual logic underlying the system, bisexuality can be included in contemporary sexual politics, sexual citizenship, and society. In other words: "hence, the bisexual 'real' is a discursive context where the nature of love changes from an exclusive, dyadic system to an inclusive one that expands beyond the dual and into the multiple" (AnderliniD'Onofrio \& Alexander 2009: 198).

Translating the deconstructing task for social scientists in the field of sex, gender, and sexualities into practice, especially within the field of geographies, I propose an approach to focus upon the everyday mundane activities and embodied practices and experiences. This approach should not been seen as replacing existing foci, but as an addition to the existing foci in the geographies of sexualities. In fact, there are many other challenges such as the demise of the gaybourhood (e.g. Brown 2014) or a new mobilities paradigm to explore lesbian, gay, bisexual, trans, and queer (GBTQ lives in the city (Nash \& Gorman-Murray 2014) which have added value for (geographical) research into bisexualities and deconstructing the binary system of sex, gender, and sexualities. These foci have much to offer too, such as questions how bisexuals and others who do not iden- tify with homonormative gay and lesbian identities experience living in such, often commodified, gay enclaves or questions related to motives why (not) living in such enclaves. The incorporation of the new mobilities paradigm reminds us to focus on concrete mobilities (and practices) "that constitute flows, patterns, and linkages amongst and between place, creating constantly reformulating relational geographies" (Nash \& Gorman-Murray 2014: 762). Informed by more-than-representational theories, queer theories, bisexual theory, and the before-mentioned speech-act theory, I propose an approach that focusses on the everyday negotiations of bisexual subjects to do or not to do their bisexuality/sexual identity. Keeping in mind the concept of feeling-by-doing and thoughtin-action, we need to understand how people act in certain encounters, and spaces, and why they act/perform the way they act/perform. In my opinion, to focus upon mundane social and sexual practices might shed light on the processes which construct and sustain the binary system on a day to day basis as it provides insight in politics and power relations that construct but also are constructed by these encounters. To understand these processes, it is important to look at the human bodies as well as the material surroundings which bisexuals encounter during their embodied everyday practices.

Based on the Klein Sexual Orientation Grid (e.g. Klein et al. 1985), bisexual practices can be identified as attraction to both men and women, sexual behaviour with men and women, and thirdly sexual fantasies about men and women. Self-identification (being, feeling bisexual) can be added as another important bisexual practice. I would like to follow recent bisexual scholarship which complicates this conceptualisation of bisexual practices by replacing "men and women" by "more-than-one gender" as the current definition of bisexual practices is too narrow to match bisexual realities (e.g. Halperin 2009; Barker et al. 2012). Indeed, people who are bisexual often look beyond categories of men and women regarding attraction, sexual behaviour, and sexual fantasies. Regarding self-identification, and I would like to add self-realisation and self-expression (see Richardson 2000), I propose a focus on language as language is not only representation, it is also a way of doing and daily practices. Language is a way of doing (and not doing) and performing (and not performing) sex, gender, and/or sexual identities. As such we can incorporate Du 
Plessis' (1996) suggestion that focussing on not doing bisexuality, or the negation of bisexuality, or passing as heterosexual/gay/lesbian might shed more light on how bisexual subjects position themselves in a society based upon compulsory monosexuality and how bisexual subjects are impacted by processes of monosexuality.

Instead of a historical and epistemological approach, the here proposed approach focusses on the present - without forgetting the past: "Memory is vital, as past (virtual) and present (actual) coexist, pushing forward in duration, the dynamic continuation of movement and sensation" (McHugh 2009: 209). While this argument focusses on the individual, the case has been made that also communities evolve through the gradual alteration of shared memories and practices - including communicative registers and routines (Lehtinen 2011).

Finally, to conceptualise bisexual spaces as spatial-temporal stabilisations of bisexual social (including linguistic) and sexual practices is not only helpful to deconstruct the functioning of the binary system of sexualities (and sex and gender), it is also helpful to identify bisexual homes and perhaps even safe havens. As stated before, Hemmings (1997) argued that specific demarcated bisexual spaces do not exist besides some conference spaces and support groups, which implies that bisexuality has no presence and no home. Again, like the Myslik (1996) study, home is translated as a space where someone is able to be oneself. I suggest, however, that bisexual spaces and homes exist in many everyday social and sexual practices - in sexy as well as in unsexy spaces (see Phillips 2006; Hubbard 2008; Caudwell \& Browne 2011).

\section{Concluding remarks}

It serves an academic and societal interest to identify bisexual spaces and articulate their existence seeing the interdependence of identities, identity negotiations, and spaces. Not in the last place because studies on the lived experiences of bisexuals - or people who desire more-than-one gender are limited in number. Awareness of this interdependence might contribute to the self-identification, self-realisation, and self-expression of bisexuals' sexual identity/identities. Identifying bisexual spaces might also stress the temporality of the sexual coding of spaces which serves a wider value, beyond the bisexual community. Recognising that different contexts impact the embodied practice and experience of everyday routines and habitual activities, also provides a temporal answer to the critique of Oswin (2008) that not only sex, gender, or sexualities is in play but also other categories such as class, race, and ethnicity. Work on queer theory failed to incorporate bisexual theories and bisexual realities, whereas queer space failed to go beyond notions of gay (and lesbian) space. In fact, it seems that queer theory only addresses and challenges heteronormativity as context and process that impacts the sexual coding of spaces and lived experiences of lesbians and gay men, instead of extending norms and incorporating other sexual minorities. Nevertheless, work on performativity is important and influences my thoughts about bisexual space. Work on queer space is important as it, theoretically, reiterates the fluidity of sex, gender, sexualities, and space.

Work on heteronormativity and monosexuality is relevant; however, I believe that the basic mode of experiencing life is the embodied and sensuous experience of the very mundane practices (and mobilities) in everyday spaces. Heteronormativity and monosexuality are indeed two important contexts, but not all determining in the everyday embodied experiences and practices of bisexuals. A longitudinal study from Finland shows, for instance, that the legal and cultural changes (e.g. the alleged increase in tolerance) in Finland regarding sexual minorities impacted the embodied experiences of Finnish bisexuals, however not to the same degree for all interviewees (Kangasvuo 2011). The story of Jonna, one of the interviewees, shows how the workplace, work environment, social environment, and internal confusion regarding sexual attraction (and identity) interact with each other and make up the daily experiences of this interviewee; the impact of legal and cultural changes seem to be rather limited in the story of Jonna.

Language plays an important role - from a speech-act theory point of view (see Brown 2000) - in experiencing life and making sense of everyday life; language does (doing-by-saying) and provides or produces meaning. Such an emphasis on language is not incompatible with an emphasis on the embodied practice and embodied experiences of bisexual individuals - bisexual bodies (see also De Plessis 1996) - and communities. The (sexualised) body communicates, in relation with different contexts, and makes sense of everyday life via the senses, gestures, actions, body language, and language itself. 


\section{REFERENCES}

Adler S \& Brenner J 1992. Gender and space: Lesbians and gay men in the city. International Journal of Urban and Regional Research 16: 1, 24-34. http://dx.doi.org/10.1111/j.1468-2427.1992.tb00463.x.

Ahmed S 2000. Strange encounters: Embodied others in post-coloniality. Routledge, London.

Alexander J \& Anderlini-D'Onofrio S 2012. Bisexuality and queer theory: Intersections, connections, and challenges. Routledge, Abingdon.

Anderlini-D'Onofrio S \& Alexander J 2009. Introduction to the special issue: Bisexuality and queer theory: Intersections, diversions, and connections. Journal of Bisexuality 9: 3-4, 197-212. http://dx.doi.org/10.1080/15299710903316489.

Anderson B 2009. Affective atmospheres. Emotion, Space and Society 2: 2, 77-81. http://dx.doi.org/10.1016/j.emospa.2009.08.005.

Anderson B \& Harrison P 2010a. Taking-place non-representational theories and geography. Ashgate, Farnham.

Anderson B \& Harrison P 2010b. The promise of nonrepresentational theories. In Anderson B \& Harrison $\mathrm{P}$ (eds). Taking-place non-representational theories and geography, 1-34. Ashgate, Farnham.

Angelides S 2001. A history of bisexuality. University of Chicago Press, Chicago.

Angelides S 2006. Historicizing (bi)sexuality. Journal of Homosexuality 52: 1-2, 125-158. http://dx.doi.org/10.1300/J082v52n01_06.

Barker M, Yockney J, Richards J , Jones R, Bowes-Catton H \& Plowman T 2012. Guidelines for researching and writing about bisexuality. Journal of Bisexuality 12: 3, 376-392.

http://dx.doi.org/10.1080/15299716.2012.702618.

Bassi D 2006. Riding the dialectical wares of gay political economy: a story from Birmingham's commercial gay scene. Antipode 38, 213-35. http://dx.doi.org/10.1111/j.1467-8330.2006.00577.x.

Bell D 1995. Bi-sexuality - A place on the margins. In Whittle S (ed). The margins of the city: Gay men's urban lives, 129-141. Ashgate, Aldershot.

Bell D, Binnie J, Cream J \&Valentine G 1994. All hyped up and no place to go. Gender Place and Culture 1: 1, 31-47. http://dx.doi.org/10.1080/09663699408721199.

Bereket T \& Brayton J 2008. "Bi" NO means: Bisexuality and the influence of binarism on identity. Journal of Bisexuality 8: 1-2, 51-61. http://dx.doi.org/10.1080/15299710802142234.

Binnie J 1997. Coming out of geography: Towards a queer epistemology? Environment and Planning D: Society and Space 15: 2, 223-237. http://dx.doi.org/10.1068/d150223.

Binnie J 2007. Sexuality, the erotic and geography: Epistemology, methodology and pedagogy. In Browne K, Lim J \& Brown G (eds). Geographies of sexualities: Theory, practices and politics, 29-38. Ashgate, Aldershot.

Binnie J \& Skeggs B 2004. Cosmopolitan knowledge and the production and consumption of sexualized space: Manchester's gay village. The Sociological Review 52, 39-61.
http://dx.doi.org/10.1111/j.1467-954X.2004.00441.x.

Binnie J \& Valentine G 1999. Geographies of sexuality - a review of progress. Progress in Human Geography 2: 2, 175-187.

http://dx.doi.org/10.1177/030913259902300202.

Bissell D 2010. Passenger mobilities: Affective atmospheres and the sociality of public transport. Environment and Planning D: Society and Space 28: 2, 270-289. http://dx.doi.org/10.1068/d3909.

Blommaert J, Collins J \& Slembrouck S 2005. Spaces of multilingualism. Language and Communication 25, 197-216. http://dx.doi.org/10.1016/j.langcom.2005.05.002.

Bowes-Catton H, Barker B \& Richards C 2011. 'I didn't know that I could feel this relaxed in my body': Using visual methods to research bisexual people's embodied experiences of identity and space. In Reavey P (ed). Visual methods in psychology: using and interpreting images in qualitative research, 255-270. Routledge, London.

Brown G 2008. Ceramics, clothing and other bodies: affective geographies of homoerotic cruising encounters. Social and Cultural Geography 9: 8, 915-932. http://dx.doi.org/10.1080/14649360802441457.

Brown G 2009. Thinking beyond homonormativity: Performative explorations of diverse gay economies. Environment and Planning $A$ 41: 6, 1496-1510. http://dx.doi.org/10.1068/a4162.

Brown G, Browne K \& Lim J 2007. Introduction, or why have a book on geographies of sexualities. In Browne K, Lim J \& Brown G (eds). Geographies of sexualities: Theory, practices and politics, 1-18. Ashgate, Aldershot.

Brown M 2000. Closet space: geographies of metaphor from the body to the globe. Routledge, London.

Brown M 2014. Gender and sexuality II: There goes the gayborhood? Progress in Human Geography 38: 3, 457-465.

http://dx.doi.org/10.1177/0309132513484215.

Browne K 2006. Challenging queer geographies. Antipode 38: 5, 885-893. http://dx.doi.org/10.1111/j.1467-8330.2006.00483.x.

Browne K 2007. (Re)making the other, heterosexualising everyday space. Environment and Planning A 39: 4, 996-1014. http://dx.doi.org/10.1068/a38165.

Browne K \& Bakshi L 2011. We are here to party? Lesbian, gay, bisexual and trans leisurescapes beyond commercial gay scenes. Leisure Studies 30: 2, 179-196. http://dx.doi.org/10.1080/02614367.2010.506651.

Butler J 1990. Gender trouble: Feminism and the subversion of identity. Routledge, London.

Butler J 1993. Bodies that matter: On the discursive limits of sex. Routledge, London.

Callis AS 2009. Playing with Butler and Foucault: Bisexuality and queer theory. Journal of Bisexuality 9: 3-4, 213-233. http://dx.doi.org/10.1080/15299710903316513.

Caudwell J \& Browne K 2011. Sexy spaces: Geography and leisure intersectionalities. Leisure Studies 30: 2, 117-122. http://dx.doi.org/10.1080/02614367.2011.561977.

Crouch D 2001. Spatialities and the feeling of doing. Social and Cultural Geography 2: 1, 61-75. 
http://dx.doi.org/10.1080/14649360020028276.

Crouch D 2003. Spacing, performing, and becoming: Tangles in the mundane. Environment and Planning A 35: 11, 1945-1960.

http://dx.doi.org/10.1068/a3585.

Duff C 2010. On the role of affect and practice in the production of space. Environment and Planning D: Society and Space 28: 5, 881-895. http://dx.doi.org/10.1068/d16209.

Duncan N 1996. Renegotiating gender and sexuality in public and private spaces. In Duncan N (ed). BodySpace: Destabilising geographies of gender and sex, 127-145. Routledge, London.

Du Plesses M 1996. Blatantly bisexual; or, unthinking queer theory. In Hall DE \& Pramaggiore M (eds). Representing bisexualities: Subjects and cultures of fluid desire, 19-54. New York University Press, New York.

Eadie J 1993. Activating bisexuality: Towards a bi/sexual politics. In Bristow J \& Wilson AR (eds). Activating theory: Lesbian, gay, bisexual politics, 31-46. Lawrence \& Wishart, London.

Erickson-Schroth L \& Mitchell J 2009. Queering queer theory, or why bisexuality matters. Journal of Bisexuality 9: 3-4, 297-315.

http://dx.doi.org/10.1080/15299710903316596.

Forrest B 1995. West Hollywood as symbol: The significance of place in the construction of a gay identity. Environment and Planning D: Society and Space 13: 2, 133-157. http://dx.doi.org/10.1068/d130133.

Foucault M 1978. The history of sexuality: Volume one. Vintage Books, New York.

Gurevich M, Bailey H \& Bower J 2009. Querying theory and politics: The epistemic (dis)location of bisexuality within queer theory. Journal of Bisexuality 9: 3-4, 235-257.

http://dx.doi.org/10.1080/15299710903316539.

Halperin D 2009. Thirteen ways of looking at a bisexual. Journal of Bisexuality 9: 3-4, 451-455. http://dx.doi.org/10.1080/15299710903316679.

Harrison P 2000. Making sense: Embodiment and the sensibilities of the everyday. Environment and Planning D: Society and Space 18: 4, 497-517. http://dx.doi.org/10.1068/d195t.

Hartman JE 2013. Creating a bisexual display: Making bisexuality visible. Journal of Bisexuality 13: 1, 39-62. http://dx.doi.org/10.1080/15299716.2013.755727.

Hemmings C 1997. From landmarks to spaces: Mapping the territory of a bisexual geneaology. In Ingram GB, Bouthillette A \& Retter Y (eds). Queers in space: Communities, public spaces, sites of resistance, 147-162. Bay Press, Seattle.

Hemmings C 2002. Bisexual spaces: A geography of gender and sexuality. London, Routledge.

Hetherington K 2003. Spatial textures: Place, touch, and praesentia. Environment and Planning A 35: 11, 1933-1944. http://dx.doi.org/10.1068/a3583.

Holt M \& Griffin C 2003. Being gay, being straight, and being yourself: Local and global reflections on identity, authenticity, and the lesbian and gay scene. European Journal of Cultural Studies 6: 3, 404-425. http://dx.doi.org/10.1177/13675494030063008.
Hubbard P 2008. Here, there, everywhere: The ubiquitous geographies of heteronormativity. Geography Compass 2: 3, 640-658. http://dx.doi.org/10.1111/j.1749-8198.2008.00096.x.

James C 1996. Dismissal and appropriation of bisexuality in queer, lesbian, and gay theory. In Beemyn B \& Liason M (eds). Queer studies: A lesbian, gay, bisexual \& transgender anthology, 217-240. New York University Press, New York.

Johnston L \& Longhurst R 2008. Queer(ing) geographies 'down under': some notes on sexuality and space in Australasia. Australian Geographer 39: 3, 247-257. http://dx.doi.org/10.1080/00049180802270457.

Johnston L \& Valentine G 1995. Wherever I lay my girlfriend, that's my home: The performance and surveillance of lesbian identities in domestic environments. In Bell D \& Valentine G (eds). Mapping desire: Geographies of sexualities, 8-103. Routledge, London.

Kangasvuo J 2011. "There has been no phase in my life when I wasn't somehow bisexual": Comparing the experiences of Finnish bisexuals in 1999 and 2010. Journal of Bisexuality 11: 2-3, 271-289. http://dx.doi.org/10.1080/15299716.2011.571989.

Kirby S \& Hay I 1997. (Hetero)sexing space: Gay men and straight space in Adelaide, South Australia. The Professional Geographer 49: 3, 295-305.

http://dx.doi.org/10.1111/0033-0124.00078.

Kitchin R \& Lysaght K 2003. Heterosexism and the geographies of everyday life in Belfast, Northern Ireland. Environment and Planning A 35: 3, 489-510. http://dx.doi.org/10.1068/a3538.

Klein F, Sepekoff B \& WolffT 1985. Sexual orientation: A multi-variable dynamic process. Journal of Homosexuality 11: 1-2, 35-49. http://dx.doi.org/10.1300/J082v11n01_04.

Knopp L 2007. From lesbian and gay to queer geographies: Past, prospects and possibilities. In Browne K, Lim J \& Brown G (eds). Geographies of sexualities: Theory, practices and politics, 21-28. Ashgate, Aldershot.

Laurier E 2010. Representation and everyday use: How to feel things with words. In Anderson B \& Harrison $\mathrm{P}$ (eds). Taking-place non-representational theories and geography, 131-146. Ashgate, Farnham.

Laurier E \& Philo C 2006. Possible geographies: A passing encounter in a café. Area 38: 4, 353-363. http://dx.doi.org/10.1111/j.1475-4762.2006.00712.x.

Lehtinen AA 2011. From relations to dissociations in spatial thinking: Sámi 'geographs' and the promise of concentric geographies. Fennia 189: 2, 14-30.

Lim J 2007. Queer critique and the politics of affect. In Browne K, Lim J \& Brown G (eds). Geographies of sexualities: Theory, practices and politics, 53-68. Ashgate, Aldershot.

Lingel J 2009. Adjusting the borders: Bisexual passing and queer theory. Journal of Bisexuality 9: 3-4, 381-405. http://dx.doi.org/10.1080/15299710903316646.

Lorimer $\mathrm{H} 2005$. Cultural geography: the busyness of being 'more-than-representational'. Progress in Human Geography 29: 1, 83-94.

http://dx.doi.org/10.1191/0309132505ph531pr. 
Lorimer H 2008. Cultural geography: Non-representational conditions and concerns. Progress in Human Geography 32: 4, 551-559. http://dx.doi.org/10.1177/0309132507086882.

Macpherson H 2009. The intercorporeal emergence of landscape: Negotiating sight, blindness, and ideas of landscape in the British countryside. Environment and Planning A 41: 5, 1042-1054. http://dx.doi.org/10.1068/a40365.

McCormack DP 2003. An event of geographical ethics in spaces of affect. Transactions of the Institute of British Geographers 28: 4, 488-507. http://dx.doi.org/10.1111/j.0020-2754.2003.00106.x.

McHugh KE 2010. Movement, memory, landscape: An excursion in non-representational thought. Geolournal 74, 209-218. http://dx.doi.org/10.1007/s10708-008-9222-0.

McLean J 2003. Daily desires: Everyday geographies of bisexual men. Simon Fraser University, Burnaby.

McLean K 2007. Hiding in the closet? Bisexuals, coming out and the disclosure imperative. Journal of Sociology 43: 2, 151-166. http://dx.doi.org/10.1177/1440783307076893.

McLean K 2008. Inside, outside, nowhere: Bisexual men and women in the gay and lesbian community. Journal of Bisexuality 8: 1-2, 63-80. http://dx.doi.org/10.1080/15299710802143174.

Middleton J 2010. Sense and the city: Exploring the embodied geographies of urban walking. Social and Cultural Geography 11: 6, 575-596. http://dx.doi.org/10.1080/14649365.2010.497913.

Myslik WD 1996. Renegotiating the social/sexual identities of places: Gay communities as safe havens or sites of resistance? In Duncan N (ed). BodySpace: Destabilising geographies of gender and sex, 155-168. Routledge, London.

Nash CJ \& Bain A 2007. 'Reclaiming raunch'? Spatializing queer identities at Toronto women's bathhouse events. Social and Cultural Geography 8: 1, 47-62. http://dx.doi.org/10.1080/14649360701251809.

Nash CJ \& Gorman-Murray A 2014. LGBT neighbourhoods and 'new mobilities': Towards understanding transformations in sexual and gendered urban landscapes. International Journal of Urban and Regional Research 38: 3, 756-772. http://dx.doi.org/10.1111/1468-2427.12104.

Nayak A 2010. Race, affect, and emotion: Young people, racism, and graffiti in the postcolonial English suburbs. Environment and Planning $A$ 42: 10, 2370-2392. http://dx.doi.org/10.1068/a42177.

Oswin N 2008. Critical geographies and the uses of sexuality: Deconstructing queer space. Progress in Human Geography 32: 1, 89-103. http://dx.doi.org/10.1177/0309132507085213.
Pennington S 2009. Bisexuals "doing gender" in romantic relationships. Journal of Bisexuality 9: 1, 33-69. http://dx.doi.org/10.1080/15299710802660029.

Phillips R 2006. Heterosexuality, respectability and the Travellers' Aid Society. ACME: An International E-Journal for Critical Geographies 5: 2, 163-190.

Richardson D 2000. Constructing sexual citizenship: Theorizing sexual rights. Critical Social Policy 20: 1, 105-135.

http://dx.doi.org/10.1177/026101830002000105.

Rothenberg T 1995. And she told two friends: Lesbians creating urban space. In Bell D \& Valentine G (eds). Mapping desire: Geographies of sexualities, 165-181. Routledge, London.

Rust P 2000. Make me a map. Journal of Bisexuality 1: 2-3, 47-108 http://dx.doi.org/10.1300/J159v01n02_03.

Sedgwick EK 1990. Epistemology of the closet. University of California Press, Berkeley.

Sibalis M 2004. Urban space and homosexuality: The example of the Marais, Paris' "Gay Ghetto". Urban Studies 41: 9, 1739-1758. http://dx.doi.org/10.1080/0042098042000243138.

Smuts L 2011. Coming out as a lesbian in Johannesburg, South Africa: Considering intersecting identities and social spaces. South African Review of Sociology 42: 3, 23-40. http://dx.doi.org/10.1080/21528586.2011.621231.

Thrift N 2007. Non-representational theory: Space, politics, affect. Routledge, London.

Valentine G 1996. (Re)Negotiating the 'heterosexual street': Lesbian productions of space. In Duncan $\mathrm{N}$ (ed). BodySpace: Destabilising geographies of gender and sex, 145-154. Routledge, London.

Valentine G 2007. Theorizing and researching intersectionality: A challenge for feminist geography. The Professional Geographer 59: 1, 10-21. http://dx.doi.org/10.1111/j.1467-9272.2007.00587.x.

Valentine G \& Skelton T 2003. Finding oneself, losing oneself: The lesbian and gay 'scene' as a paradoxical space. International Journal of Urban and Regional Research 27: 4, 849-866. http://dx.doi.org/10.1111/j.0309-1317.2003.00487.x.

Visser G 2008. The homonormalisation of white heterosexual leisure spaces in Bloemfontein, South Africa. Geoforum 39: 3, 1347-1361. http://dx.doi.org/10.1016/j.geoforum.2007.11.004. Visser G 2013. Challenging the gay ghetto in South Africa: Time to move on? Geoforum 49, 268-274. http://dx.doi.org/10.1016/j.geoforum.2012.12.013.

Yoshino K 2000. The epistemic contract of bisexual erasure. Stanford Law Review 52, 353-461. http://dx.doi.org/10.2307/1229482. 